Reason and Passion 



\section{Reason and Passion}

Representations of Gender

in a Malay Society

MICHAEL G. PELETZ

University of California Press

BERKELEY LOS ANGELES LONDON 
Univèrsity of California Press

Berkeley and Los Angeles, California

University of California Press, Ltd.

London, England

(C) 1996 by the Regents of the University of California

Parts of this book were published in earlier versions.

Parts of chapters 1 and 2: A Share of the Harvest: Kinship, Property, and Social History among the Malays of Rembau (Berkeley:

University of California Press, 1988).

Parts of chapter 2: "The Exchange of Men in Nineteenth-Century

Negeri Sembilan (Malaya)," American Ethnologist 14, no. 3 (1987).

Reprinted by permission of the American Anthropological

Association. Not for further reproduction.

Parts of chapter 4: "Knowledge, Power, and Personal Misfortune in a

Malay Context," in Understanding Witchcraft and Sorcery in

Southeast Asia, edited by C. W. Watson and Roy F. Ellen (Honolulu: University of Hawaii Press, 1993). Reprinted by permission of the

University of Hawaii Press. "Poisoning, Sorcery, and Healing Rituals in Negeri Sembilan," Bijdragen tot de Taal-, Land-, en Volkenkunde

144, no. 1 (1988). Reprinted by permission of the Koninklijk Instituut voor Taal-, Land-, en Volkenkunde, Leiden.

Parts of chapter 6: "Neither Reasonable nor Responsible: Contrasting Representations of Masculinity in a Malay Society," Cultural Anthropology 9, no. 2 (1994). Reprinted by permission of the American Anthropological Association.

Library of Congress Cataloging-in-Publication Data

Peletz, Michael G.

Reason and passion : representations of gender in a Malay society / Michael G. Peletz.

p. $\mathrm{cm}$.

Includes bibliographical references (p. ) and index.

ISBN 0-520-20069-1 (alk. paper).-ISBN 0-520-20070-5 (pbk. : alk. paper)

1. Malays (Asian people)-Malaysia-Negeri Sembilan-

Kinship. 2. Malays (Asian people)-Malaysia-Negeri SembilanSocial conditions. 3. Gender identity-Malaysia-Negeri

Sembilan. 4. Sex role-Malaysia-Negeri Sembilan. 5. Matrilineal kinship-Malaysia-Negeri Sembilan. 6. Negeri Sembilan-Social life and customs. I. Title.

DS595.P45 1996

$305.3^{\prime} 09595^{\prime} 1$-dc20

$94-45698$

Printed in the United States of America

987654321

The paper used in this publication meets the minimum requirements of American National Standard for Information Sciences-Permanence of Paper for Printed Library Materials, ANSI Z39.48-1984. 
For my parents,

Cyril M. and Shirley G. Peletz 
